\title{
DINAMIKA KEKUASAAN, ISLAM DAN WARISAN BUDAYA DI BANJARNEGARA
}

\author{
Sofa Marwah \\ Universitas Jenderal Soedirman \\ Jl. HR Bunyamin No. 999, Kampus Grendeng, Purwokerto \\ Email: sofamarwah75@gmail.com
}

Abstract: This study describe the dynamics of a power in Banjarnegara and to study Islam and its cultural heritage. Banjarnegara is located far from negarigung; hence, it does not become the focus study of experts. Nevertheless, Banjarnegara's history and its culture are precious. This study is a library research based on many sources talked about Banjarnegara. The result shows that the power ruling in Banjarnegara is hereditary, but then, it has to fight against the colonial politics and higher power caused this hereditary is useless. The dynamics of a power in Banjarnegara also takes a part in developing Islam as the Walisanga ancestry are prominent figures in the area. Along with the power of Mataram, the palace gave the status of a perdikan in Kademangan Gumelem, as storage of palace's heirlooms and burial of Islamic leaders in Banjarnegara. At this moment, Gumelem is the center of nyadran gede held by local government, a good way to fuse previous legacies and present authorities. Gumelem also bequeaths traditional batik as one of palace legacies.

Keywords: dynamics, power, Islam, and culture

Abstrak: Studi ini bertujuan menggambarkan dinamika kekuasaan di Banjarnegara dan mengkaji Islam dan warisan budayanya. Banjarnegara jauh dari negarigung yang kurang menjadi fokus para ahli. Padahal sisi historis dan budayanya mewariskan budaya yang berharga. Studi ini merupakan library research yang mendialogkan berbagai karya terkait Banjarnegara. Hasil kajian menunjukkan bahwa penguasa Banjarnegara mendasarkan pada keturunan, yang pada saatnya harus berhadapan dengan kekuatan politik kolonial dan penguasa di atasnya, sehingga keturunan tidak lagi menjadi pertimbangan. Dinamika kekuasaan di Banjarnegara juga terkait dengan perkembangan Islam oleh keturunan Walisanga, yang menurunkan tokoh-tokoh besar di Banjarnegara. Pada masa Mataram, keraton memberikan status wilayah perdikan di Kademangan Gumelem, sebagai 
penyimpanan pusaka kerajaaan dan pemakaman tokoh-tokoh Islam. Saat ini wilayah Gumelem menjadi pusat nyadran gede yang diselenggarakan oleh pemerintah daerah. Sebuah cara elok untuk menyatukan warisan masa lalu dengan kepemimpinan masa kini, yaitu dengan menghormati para leluhur. Gumelem juga mewariskan batik tradisional yang merupakan warisan budaya keluarga keraton.

Kata kunci: dinamika, kekuasaan, Islam, budaya

\section{A. Pendahuluan}

Studi tentang perkembangan suatu daerah atau perkotaan di Indonesia diwarnai oleh penggambaran berbagai aspek, seperti politik pemerintahan, ekonomi, sosial, agama, yang dipotret dalam konteks kehidupan masyarakat masa tertentu. Studi Sunardjo (1983) misalnya, menulis tentang perkembangan Cirebon yang mencapai puncak kejayaannya pada pemerintahan Syarif Hidayatullah atau Sunan Gunung Jati (1479-1568) sebagai kerajaan besar yang bercorak Islam yang merdeka. Studi lainnya dari Supriyono (2013) mengkaji sejarah Jepara sebagai kerajaan maritim dan kota pelabuhan, yang ditunjukkan kemampuan armada laut Ratu Kalinyamat yang pernah dua kali mengusir Portugis di Malaka tahun 1551 M dan 1574 M. Selanjutnya studi Yulianingsih dan Hariyono (2012) menggambarkan perkembangan gemeente Mojokerto tahun 1918-1942 yang berdampak pada perbaikan sarana dan prasarana kehidupan sosial dan masuknya pribumi dalam strukt ur pemerintahan. Studi lain oleh Pambudi dan Murdiyastomo (2013) mengenai perubahan Menoreh menjadi Temanggung tahun 1834 yang menandai perubahan sosial, politik, ekonomi di Jawa abad ke-19. Ketika itu Belanda mengembangkan lahan perkebunan di Temanggung untuk kepentingan ekspor. Studi dari Mulyasari (2014) membahas pertumbuhan kota Purwokerto awal abad ke-20 yang lebih cepat dibanding kota-kota disekitarnya akibat pembaharuan oleh kolonial Belanda melalui pembangunan jalur tram, jalur kereta api, dan pembangunan pabrik gula.

Berbagai studi di atas kurang mengkaitkan antara dinamika kekuasaan di masa lalu yang sesungguhnya banyak berkaitan dengan perkembangan Islam. Untuk itu studi ini bertujuan untuk menggambarkan dinamika kekuasaan sebuah wilayah yaitu Banjarnegara yang tidak dapat dipisahkan dari perkembangan Islam beserta warisan berharga yang ditinggalkannya saat ini. 
Banjarnegara adalah sebuah kabupaten yang terletak di barat daya Provinsi Jawa Tengah. Banjarnegara bukanlah wilayah negarigung, bukanlah pesisir. Letaknya termasuk mancanegara namun memiliki keeksotisan warisan budaya tinggalan masa lalu, selain alam yang sangat indah. Mungkin banyak orang mengenai sisi historis dan budaya masyarakat Banjarnegara hanya melalui komunitas Dieng yang merepresentasikan masyarakat kuno pusat budaya Hindu sejak Abad 4/5 yang lalu. Masyarakat Dieng sudah dikenal dengan budaya ruwatan rambut gimbal. Namun sesungguhnya nilai kesejarahan dan budaya Banjarnegara bukan hanya itu. Banyak sisi historis dan tradisi budaya lain yang pat dipahami dan dijaga sebagai warisan yang begitu berharga.

Pemilihan Banjarnegara juga mengingat studi mengenai sejarah dan budaya daerah tersebut sangat minim. Kekuasaan Orde Baru telah membukakan kenyataan bahwa keanekaragaman historis dan sejarah di berbagai pelosok Nusantara seolah lenyap di tengah upaya rezim untuk Orde Baru menempatkan budaya daerah sebagai unsur budaya nasional dan oleh karenanya harus senantiasa tunduk pada program Direktorat Kebudayaan yang bertugas menata kebudayaan nasional (Jones, 2015 : 315). Sentralisasi pengelolaan kebijakan budaya daerah sesungguhnya telah meminggirkan penggambaran pentingnya kajian yang menyeluruh mengenai sisi historis dan budaya di berbagai daerah pelosok, jauh dari hituk pikuk studi tentang negarigung, tentang Yogyakarta ataupun Surakarta.

Untuk memperoleh gambaran tentang dinamika dalam praktik kekuasaan di Banjarnegara, sekaligus perkembangan Islam di Banjarnegara beserta warisan budayanya, maka tulisan ini dibagi dalam tiga bagian; bagian pertama menyajikan dinamika kekuasaan di Banjarnegara; bagian kedua menyajikan persinggungan perkembangan Islam di Banjarnegara dengan wilayah perdikan, yaitu Gumelem. Bagian terakhir merupakan kesimpulan yang menyajikan skema suksesi kekuasaan di Banjarnegara; keterkaitan perkembangan historis Banjarnegara dengan penyebaran Islam dan implikasikasinya terhadap keberadaan perdikan Gumelem, sekaligus meneguhkan tradisi budaya melalui batik tradisional. Artikel ini merupakan hasil dari studi kepustakaan atau library research (Bakker dan Zubair, 1990: 63). Sebagai library research, penulis melakukan dialog dengan berbagai karya tulis, terutama hasil kajian dari Adisarwono (tanpa tahun); Sudarmo dan Purwoko (tanpa tahun); Rachman (2010); Ardhanariswari (2014). Beberapa kajian tersebut telah mengait- 
kan studinya dengan babad kuno yang terkait dengan Banjarnegara. Dialog juga dilakukan dengan berbagai buku, jurnal, dan dokumen lainnya yang masih berkaitan dengan sejarah Banjarnegara. Data yang dapat dikumpulkan dari library research kemudian dianalisis sehingga berbagai asumsi tentang berlangsungnya tradisi kekuasaan wilayah Banjarnegara, perkembangan Islam, dan budaya yang diwariskan, dapat dieksplorasi dan mengantarkan penulis pada temuan-temuan.

\section{B. Dinamika Kekuasaan di Banjarnegara: Asal Mula Ber- Diri Hingga Politik Modern}

Dinamika kekuasaan Banjarnegara tidak bisa dilepaskan dari asal usul dan perkembangan Banyumas. Kajian mengenai asal mula dan perkembangan daerah Banyumas merujuk pada dua babad utama yaitu, Babad Pasir dan Babad Banyumas. Kedua babad tersebut berkaitan dengan babad-babad kecil lainnya, yaitu; Babadipun Dusun Perdikan Gumelem, Babad Noesa Tembini, Babad Onje, Babad Jambukarang, dan babad-babad lainnya (Priyadi, 2005). Dengan demikian jelas, bahwa dinamika kekuasaan Banjarnegara tidak bisa dipisahkan dari asal mula berdirinya Banyumas.

Babad Pasir terut ama menjelaskan keterkait an Pasirluhur dengan Kerajaan Pajajaran, sedangkan Babad Banyumas mengemukakan hubungan Kadipaten Wirasaba sebagai klien dari patronnya, Kerajaan Majapahit. Pasirluhur adalah kerajaan merdeka yang terletak di antara Pejajaran dan Majapahit, tepatnya di sebelah barat kota Purwokerto sekarang (Desa Pasir). Sejarah Banyumas sudah banyak ditulis oleh para ahli, seperti Adisarwono (1992); Priyadi (2002; 2011); Herusatoto (2008); dan sebagainya. Seperti dinyatakan oleh para ahli tersebut, sejarah Banyumas berhubungan dengan Babad Pasir yang mengkaitkan genealogis masyarakat Banyumas dengan Kerajaan Padjajaran, serta Babad Banyumas yang mengkaitkan leluhur masyarakat Banyumas dengan Kerajaan Majapahit. Khususnya mengenai Babad Banyumas, babad tersebut mengkisahkan pembagian Wirasaba menjadi empat daerah pada masa Kerajaan Pajang. Ketika itu, Sultan Pajang menetapkan Joko Kaiman sebagai Adipati Wirasaba VII dengan gelar nunggak semi yaitu Warga Utama II pada tahun 1571, karena statusnya sebagai menantu Warga Utama I.

Suksesi politik kemudian berlanjut dengan keputusan Joko Kaiman untuk membagi daerah Wirasaba menjadi empat, yaitu: 1) Wirasaba diserah- 
kan pada Ngabehi Wargawijaya (putra kedua Warga Utama I) dengan kekuasaan meliputi utara Sungai Serayu-Pegunungan Perahu, seperti Sokaraja Lor, Wirasaba, dan Kali Merawu; 2) Mreden pada Ngabehi Wirakusuma (putra ketiga Warga Utama I), meliputi pesisir laut yaitu pesisir Laut Kidul, Sungai Citanduy, dan Pegunungan Kendheng; 3) Banjar Pertambakan diserahkan pada Ngabei Wirayuda (putra keempat Warga Utama I), meliputi Kali Merawu, Dataran Tinggi Dieng, Pegunungan Kendheng; 4) Kejawar dipimpin Joko Kaiman dengan kekuasaan meliputi selatan Pegunungan Perahu, Ajibarang, Wangon, Sampang, dan Tambak (Herusatoto, 2008:63).

Pembagian keempat daerah tersebut konon menjadi cikal bakal berkembangnya empat kabupaten pada masa sekarang, yaitu Kejawar menjadi Kabupaten Banyumas, Wirasaba menjadi Purbalingga, Banjar Pertambakan menjadi Banjarnegara, dan Mreden menjadi Kabupaten Cilacap. Keempat daerah tersebut bisa dikatakan memiliki sejarah genealogis dan akar tradisi yang relatif sama. Ketika kolonial Belanda berkuasa, keempatnya disatukan menjadi Karesidenan Banyumas pada 1 Januari 1936. Penting untuk diketahui pula bahwa Pemerintah Kabupaten (Pemkab) Banyumas menetapkan 22 Februari sebagai Hari Jadi Banyumas melalui Perda Kabupaten Banyumas No 10 Tahun 2015 tentang Hari Jadi Banyumas. Berdasarkan studi dari Priyadi (2011) bahwa 22 Pebruari 1571 adalah tanggal dan tahun pengangkatan Joko Kaiman sebagai Adipati Wirasaba menggantikan mertuanya, Warga Utama I. Perda No 10 Tahun 2015 tersebut mencabut Perda No 2 Tahun 1990 tentang Hari Jadi Kabupaten Banyumas. Pada perda tersebut, ditetapkan bahwa Hari Jadi Banyumas adalah 6 April 1582 yang dianggap sebagai hari dan tanggal pengangkatan Joko Kaiman sebagai adipati oleh Sultan Pajang. Namun setelah dilakukan berbagai kajian lagi maka ditetapkan bahwa tanggal dan hari pengangkatan Joko Kaiman sebagai adipati adalah 22 Februari 1571 sehingga hari tersebut ditentukan sebagai Hari Jadi Kabupaten Banyumas.

Khususnya mengenai pemerintahan Ngabei Wirayuda di Banjar Pertambakan, tidak ada sumber tertulis yang secara jelas menggambarkan perkembangannya. Dimungkinkan pemerintahan tersebut tidak lestari atau tidak berkembang (Adisarwono, tanpa tahun : 68). Terdapat tiga kemungkinan berkaitan dengan hal tersebut; Pertama, masa setelah pembagian Wirasaba tersebut, situasi politik ditandai dengan jatuhnya kekuasaan patron Wirasaba, yaitu Kerajaan Pajang yang digantikan Kerajaan Mataram (Muljana, 2009: 33); Kedua, sebagai kerajaan yang baru berdiri, Mataram masih fokus pada 
konsolidasi politik yang belum stabil di pusat kekuasaan; Ketiga, masa setelah it u juga ditandai mulai masuknya pengaruh kolonial Belanda di wilayah mancanegara yang letaknya jauh dari pusat kekuasaan (negarigung), termasuk Banyumas dan sekitarnya.

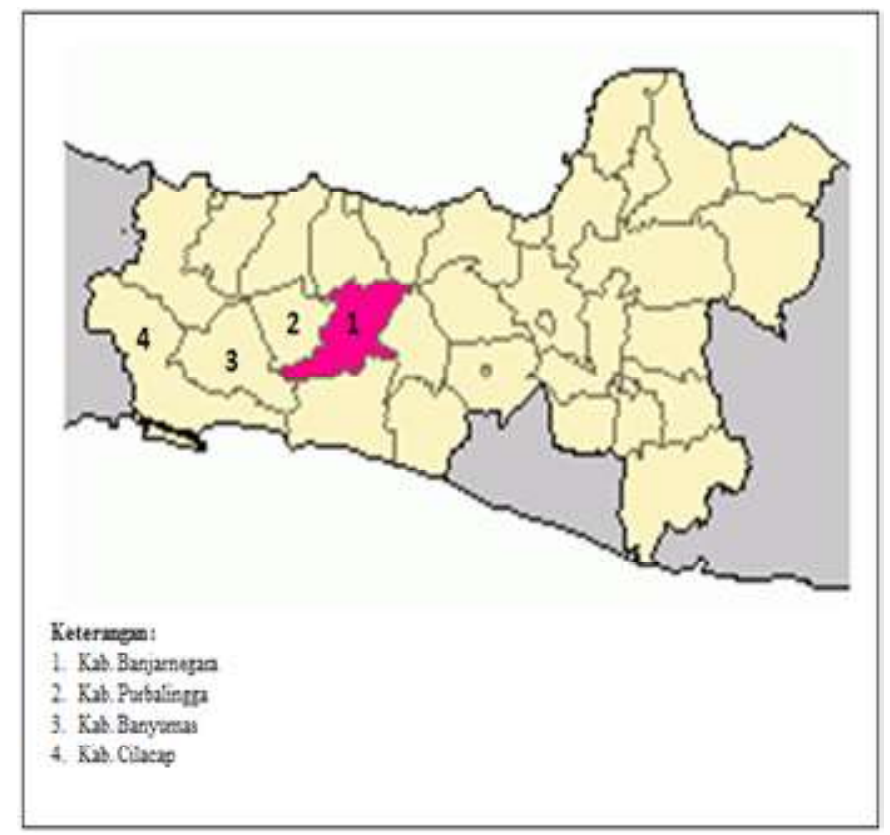

Gambar 1. Peta Kabupaten Banjarnegara dan sekitarnya

Setelah pemerintahan Ngabei Wirayuda, diketahui kemudian daerah Banjar Pertambakan dipimpin oleh Banyak Wide (Adisarwono, tanpa tahun: 59). Banyak Wide adalah putra Adipati Mertayuda I yang menjabat sebagai bupati Banyumas ke-4 setelah Joko Kaiman. Hal it u berarti ketika di Banyumas sudah terjadi suksesi kepemimpinan empat kali, mulai dari Joko Kaiman, Adipati Jannah I, Adipati Jannah II (Mertayuda I), dan Yudanegara (Mertayuda II), namun di Banjarnegara hanya tercatat Banyak Wide yang memerintah. Setelah pemerintahan Banyak Wide, kepemimpinan di Banjar Pertambakan digantikan oleh Mangunyuda I. Kelak Mangunyuda I gugur melawan kolonial Belanda dalam pemberontakan Tionghoa yang disebut Perang Pacina. Ketika itu, perjuangan Mangunyuda I dalam membantu Kasunanan Surakarta dilaksanakan bersama-sama dengan Yudanegara II yang saat itu menjabat sebagai Adipati Banyumas.

Setelah Mangunyuda I gugur dalam Perang Pacina, kemudian terjadi 158 Vol. 17, No. 1, Mei 2019 - ISSN: $1693-6736$ 
suksesi kepemimpinan oleh adik Mangunyuda I, yang selanjutnya bergelar Mangunyuda II. Pada masa pemerintahan Mangunyuda II ini terjadi pemindahan pusat pemerintahan dari Banjar Pertambakan ke Banjar Watu Lembu. Selain itu, kepemimpinan Mangunyuda II digambarkan sebagai seorang pemimpin yang gigih dan gagah berani mendukung perjuangan Pangeran Diponegoro. Dukungan yang diberikan oleh Mangunyuda II terhadap perjuangan Pangeran Diponegoro sekaligus menandai perlawanan Mangunyuda II terhadap Kasunanan Surakarta. Kegigihan Mangunyuda II dalam mendukung perjuangan Pangeran Diponegoro yang berarti menentang Kasunanan Surakarta menjadikan status Banjar Watu Lembu sebagai kabupaten berakhir. Ketika Mangunyuda II digantikan putranya (Mangunyuda III), status Banjar Watu Lembu sudah diturunkan menjadi distrik.

Selanjutnya terjadi suksesi kepemimpinan dari Mangunyuda III ke Dipayuda IV. Dalam hal ini Dipayuda IV memindahkan pusat kekuasaan dari Banjar Watu Lembu ke Banjarnegara. Pengangkatan Dipayuda IV menjadi adipati Banjarnegara tidak bisa dilepaskan dari balas jasa atas dukungan Dipayuda terhadap Kasunanan Surakarta. Terbentuknya kabupaten Banjarnegara sekaligus menghilangkan stat us kabupaten Banjar Watu Lembu pada tahun 1831 M. Sebagai pemimpin pemerintahan, Dipayuda dikenal dengan upayanya untuk mengembangkan Banjarnegara. Jasa pemerintaan Adipati Dipayuda antara lain terlihat dari pembangunan alun-alun Banjarnegara, pendapa pemerintahan, kepatihan, masjid besar, pasar, dan sebagainya (Adisarwono, tanpa tahun : 42).

Perlu diketahui bahwa Dipayuda IV adalah putra Dipayuda III atau anak Ki Arsantaka. Ketika terjadi pemberontakan Pangeran Mangkubumi terhadap Kasunanan Surakarta, Ki Arsantaka bekerjasama dengan Dipayuda I membantu Kasunanan Surakarta (Paku Buwono II) yang didukung kolonial Belanda untuk menyerang pasukan Pangeran Mangkubumi. Dipayuda I merupakan adipati pertama di daerah yang sekarang dikenal dengan Kabupaten Purbalingga. Ketika Dipayuda I gugur, penggantinya adalah Dipayuda II yang tidak lama memimpin karena sakit-sakit an dan meninggal. Pada masa Dipayuda III, atas saran Ki Arsantaka, Purbalingga ditetapkan sebagai pusat pemerintahan dengan pembangunan pendapa dan alun-alun, yaitu pada tahun 1789 M (Atmo, tanpa tahun : 36).

Pengangkatan Dipayuda pada tanggal 22 Agust us 1831 M sebagai 
bupati Banjarnegara oleh Gubernur Jenderal Hindia Belanda sampai saat ini diperingati sebagai Hari Jadi Kabupaten Banjarnegara. Pemkab Banjarnegara menuangkan keput usan tersebut dalam Perda No. 3 Tahun 1994 tentang Hari Jadi Kabupaten Banjarnegara. Pada masa pemerintahannya, Adipati Dipayuda juga memindahkan ibukota pemerintahan dari Banjar Watu Lembu ke kota Banjarnegara. Pada masa sekarang peringatan Hari Jadi Kabupaten Banjarnegara ditandai dengan ritual Kirab Panji Lambang Daerah dari Desa Banjarkulon Kecamatan Banjarmangu menuju pendapa Dipayuda Banjarnegara.

Adipati Dipayuda menjabat bupati Banjarnegara sampai tahun 1846. Penggantinya adalah Dipodiningrat yang pensiun tahun 1878. Namun Bupati Banjarnegara berikutnya diambil dari Kabupaten Purworejo yaitu Tumenggung Jayanegara I. Ketika Jayanegara I wafat, digantikan oleh putranya Jayanegara II. Pengganti Jayanegara II adalah Raden Sumitro Kalapaking yang masih keturunan Raden Dipodiningrat dari pihak ibunya. Sumitro Kalapaking masih memerintah ketika Banjarnegara dimasukkan sebagai Karesidenan Banyumas pada tahun 1936. Bahkan kekuasaan Sumitro Kalapaking sebagai bupati berlangsung hingga kemerdekaan, yaitu 1949 (Sudarmo dan Purwoko, tanpa tahun : 165).

Setelah masa kemerdekaan sampai era Orde Lama, Kabupaten Banjarnegara diperintah oleh Raden Sumarto sejak 1949-1960. Masih pada era Orde Lama pula, Banjarnegara dipimpin oleh Raden Mas Soedjirno yang berkuasa antara 1960-1967. Seiring pergantian kekuasaan pada tingkat nasional, yaitu dari rezim Orde Lama ke Orde Baru, Kabupaten Banjarnegara dipimpin oleh Raden Soedibjo yang memimpin ant ara tahun 1967-1973. Berturut-turut selanjutnya Soewardji memerintah Kabupaten Banjarnegara sejak 1973-1980. Adapun penggantinya adalah Winarno Surya Adisubrata yang berkuasa antara 1980-1986. Suksesi pemimpin berikutnya yaitu oleh Endro Soewarjo yang memerintah di Kabupaten Banjarnegara 1986-1991. Selanjutnya Kabupaten Banjarnegara dipimpin oleh Nurachmad yang berkuasa antara 1991-2001. Kepemimpinan politik di Kabupaten Banjarnegara selanjutnya dipegang oleh Djasri yang berkuasa di Banjarnegara selama dua periode berturut-turut yaitu 2001-2006 dan 2006-2011. Kepemimpinan Djasri pada periode kedua, 2006-2011, yaitu melalui pelaksanaan pemilihan kepala daerah (pilkada) langsung pertama di Kabupaten Banjarnegara sesuai dengan amanat Undang-Undang No. 32 Tahun 2004 tentang Pemerintahan Daerah 
(Pasal 56 Ayat 1 mengatur pemilihan kepala daerah secara langsung). Selanjutnya Kabupaten Banjarnegara dipimpin oleh Sutedjo Slamet Utomo yang terpilih melalui pilkada langsung sebagai Bupati Banjarnegara periode 2011-2016. Pada penyelenggaraan pilkada terakhir, yaitu pada 2017, pasangan Budi Sarwono dan Syamsudin berhasil menduduki tampuk kekuasaan di Banjarnegara. Satu catatan yang penting untuk disimak bahwa Kabupaten Banjarnegara sejak dikenal dengan daerah Banjarpertambakan masa pemimpin Ngabehi Wirayuda, Banyak Wide, dan seterusnya hingga masa Mangunyuda, Dipayuda, masa kemerdekaaan, hingga era reformasi sekarang ini, belum memiliki pemimpin perempuan seorang pun. Dalam hal ini para figur perempuan tenggelam dalam dominasi laki-laki yang memegang peran sentral dalam dinamika kekuasaan di Banjarnegara pada masa lalu dan sekarang.

\section{Perkembangan Islam Di Banjarnegara Beserta Warisan BuDAYANYA}

Dinamika kekuasaan di bumi Banjarnegara tidak dapat dilepaskan dari kisah Islam masuk tumbuh dan berkembang di wilayah tersebut. Secara geografis, Banjarnegara tidak terletak di pesisir utara Jawa, namun di kawasan pedalaman jika dilihat dari skema pesisir-pedalaman. Seperti diketahui bahwa kawasan pesisir utara adalah basis penyebaran agama Islam di tanah Jawa. Jika dilihat kondisi geografisnya, Banjarnegara utara mempunyai akses yang mudah ke Pekalongan yang termasuk kawasan pesisir utara Jawa. Kemudahan jalur ke wilayah pesisir inilah yang memungkinkan mudahnya Islam masuk dan berkembang di Banjarnegara. Khususnya di Banjarnegara bagian utara, masyarakat daerah dikenal memiliki corak ke-Islaman yang lebih kuat.

Kisah Islam bermula dan perkembangannya di Banjarnegara terkait dengan keberadaan tokoh Pangeran Giri Wasiyat dan Pangeran Giri Pit. Kedua tokoh tersebut berhubungan erat dengan perkembangan Islam di Gresik Jawa Timur karena keduanya adalah putra Sunan Giri. Seperti diketahui Sunan Giri adalah salah seorang Walisanga yang berkedudukan di Gresik. Jamak diketahui bahwa tanah Jawa memiliki sembilan wali yang sangat disegani hingga hari ini, yaitu : 1) Maulana Malik Ibrahim yang berkedudukan di Gresik; 2) Sunan Ampel berkedudukan di Ampel Surabaya; 3) Sunan Kudus yang menjadi Senapati Demak ketika menaklukkan Majapahit; 4) Sunan Bonang yang merupakan putra dari Sunan Ampel; 5) Sunan Drajat yang juga putra Sunan Ampel berkedudukan di Lamongan; 6) 
Sunan Giri yang berkedudukan di Gresik yang dikenal sebagai anak asuh dan murid Sunan Ampel;7) Sunan Kalijaga berkedudukan di Demak; 8) Sunan Muria yang menjadi putra Sunan Kalijaga; 9) Sunan Gunung Jati atau Syarif Hidayatullah yang mendirikan Kasultanan Cirebon.

Dikisahkan bahwa Pangeran Giri Wasiyat dan Pangeran Giri Pit bersama saudara putrinya yang bernama Nyai Sekati melakukan perjalanan ke arah barat dan sampai di daerah yang bernama Banjar. Perlu diketahui bahwa desa Banjar tersebut telah dirintis perkembanganya oleh Ki Maliu sebagai desa yang subur dengan areal persawahan yang luas. Desa Banjar merupakan lumbung padi bagi daerah sekitarnya. Kelak desa Banjar inilah yang berkembang menjadi Banjarpertambakan (sebelah timur Kali Merawu) dan selanjutnya dipindah ke sebelah barat Kali Merawu dan menjadi ibu kota yang dikenal dengan nama Banjar Watu Lembu pada masa pemerintahan Mangunyuda II (Adisarwono, tanpa tahun : 100).

Kedatangan Pangeran Giri Wasiyat beserta saudara-saudaranya menjadikan desa Banjar semakin berkembang. Kedatangan Pangeran Giri Wasiyat diterima dengan tangan terbuka oleh Ki Maliu dan masyarakat setempat. Bahkan kemudian Ki Maliu menjadi menantu Pangeran Giri Pit. Sesuai pesan ayahandanya (Sunan Giri), Pangeran Giri Wasiyat dan Giri Pit terus menerus melakukan syiar Islam melalui pengajian dan sebagainya. Selanjutnya Pangeran Giri Wasiyat menetap dan mengembangkan Islam dengan mendirikan masjid dan pondok pesantren di wilayah yang sekarang masuk Kecamatan Punggelan Kabupaten Banjarnegara. Adapun Nyai Sekati sebagai satu-sat unya tokoh perempuan yang terlibat dalam pengembangan Islam di Banjarnegara akhirnya menetap di dukuh Karangtengah, termasuk Kecamatan Wanayasa sekarang ini. Anak turun Pangeran Giri Wasiyat dan Pangeran Giri Pit kelak di kemudian hari menurunkan tokoh-tokoh penting dalam pemerintahan Banjarnegara, seperti adipati Banyak Wide yang menjadi bupati Banjar pertama, dan Adipati Mangunyuda I dan Mangunyuda II yang menjadi bupati Banjar kedua dan ketiga.

Selanjutnya perkembangan Islam di Banjarnegara juga tidak dapat dilepaskan dari keberadaan tokoh Islam Ki Ageng Giring dan Ki Ageng Gumelem. Hingga saat ini masyarakat Gumelem Banjarnegara mewarisi babad Babad Babadipun Dusun Perdikan Gumelem yang berkait an dengan teks-teks dalam Babad Onje, Babad Purbalingga, Babad Kaligenteng, Babad 
Ajibarang, Babad Noesa Tembini, di mana babad-babad kecil tersebut berkaitan dengan dua babad besar yang menaungi yaitu Babad Banyumas dan Babad Pasir (Priyadi, 2002).

Keberadaan Ki Ageng Giring tidak bisa dilepaskan dari nama besar Ki Ageng Pemanahan, ayahanda Sutawijaya. Kedua tokoh tersebut bersahabat dan berlanjut dengan hubungan sebagai besan, yaitu menikahkan putri Ki Ageng Giring yang bernama Nawangwulan dengan putra Ki Ageng Pemanahan, Sutawijaya. Sejarah mencatat bahwa kelak Sutawijaya terseret drama politik perebutan tahta di Kerajaan Demak dengan membantu Jaka Tingkir (Hadiwijaya) untuk menyingkirkan Arya Penangsang. Setelah Arya Penangsang terbunuh, Hadiwijaya memindahkan pusat kerajaan Demak ke Kerajaan Pajang. Atas jasa-jasanya, Sutawijaya bersama-sama ayahnya Ki Ageng Pemanahan dan Ki Juru Martani dianugerahi daerah Mataram. Ki Ageng Pemanahan dibantu anaknya Sutawjaya dan Ki Juru Martani mengembangkan daerah Mataram di bawah kekuasaan Pajang. Namun sejak Ki Ageng Pemanahan meninggal, Sutawijaya mulai membangun kekuatan dan membangkang perintah Kerajan Pajang. Setelah Sultan Hadiwijaya wafat, Sutawijaya mendirikan Kerajaan Mataram dengan ibukota di Kotagede (Muljana, 2009: 263-264). Sutawijaya kemudian bergelar Panembahan Senopati ing Alaga Abdurahman Khalifatullah Sayidin Panatagama dan melebarkan kekuasaannya ke wilayah Jawa Timur dan Jawa Tengah, termasuk wilayah Banyumas dan sekitarnya.

Sementara itu, Ki Ageng akhirnya melakukan perjalanan meninggalkan kampung halaman dengan Nawangwulan agar keberadaan anak Nawangwulan dan Sutawijaya diakui oleh ayahnya. Pada akhirnya Nawangwulan memutuskan menetap di wilayah yang saat ini dikenal sebagai Selamerta di Kecamatan Mandiraja Banjarnegara. Adapun Ki Ageng Giring akhirnya menetap di daerah yang saat ini disebut Majatengah Kecamatan Bukateja Purbalingga, dengan mengembangkan pesantren di wilayah tersebut. Ketika Ki Ageng Giring wafat, jenazahnya akan dimakamkan di Selamerta namun hilang saat tiba di Gumelem. Pada saat bersamaan, Panembahan Senopati memerlukan jimat Ki Sodor dan Ganjur milik Ki Ageng Gumelem. Ki Ageng Gumelem juga telah berhasil memberantas pemberontakan di Gunung Tidar yang didalangi oleh Wirakusuma. Sebagai tanda terima kasih, Ki Ageng Gumelem dianugerahi tanah di suatu daerah di Lembah Tidar, di ujung Pegunungan Kendeng namun ditolaknya. Sebagai gantinya, Panembahan 
Senapati memberikan Gumelem dan menjadikan Ki Ageng Gumelem beserta keturunannya sebagai demang di daerah tersebut. Kemudian dia juga diberi kesempatan memilih pusaka di keraton Mataram. Beliau memilih pusaka tanpa wrangka, jubah, dan surban, yang maknanya adalah kebebasan. Panembahan Senopati kemudian menetapkan wilayah Gumelem sebagai tanah perdikan, yaitu wilayah yang diberi hak istimewa untuk tidak dipungut pajak. Tugas utama Ki Ageng Gumelem adalah memelihara makam Ki Ageng Giring di Bukit Girilangan (Adisarwono, tanpa tahun : 171-173).

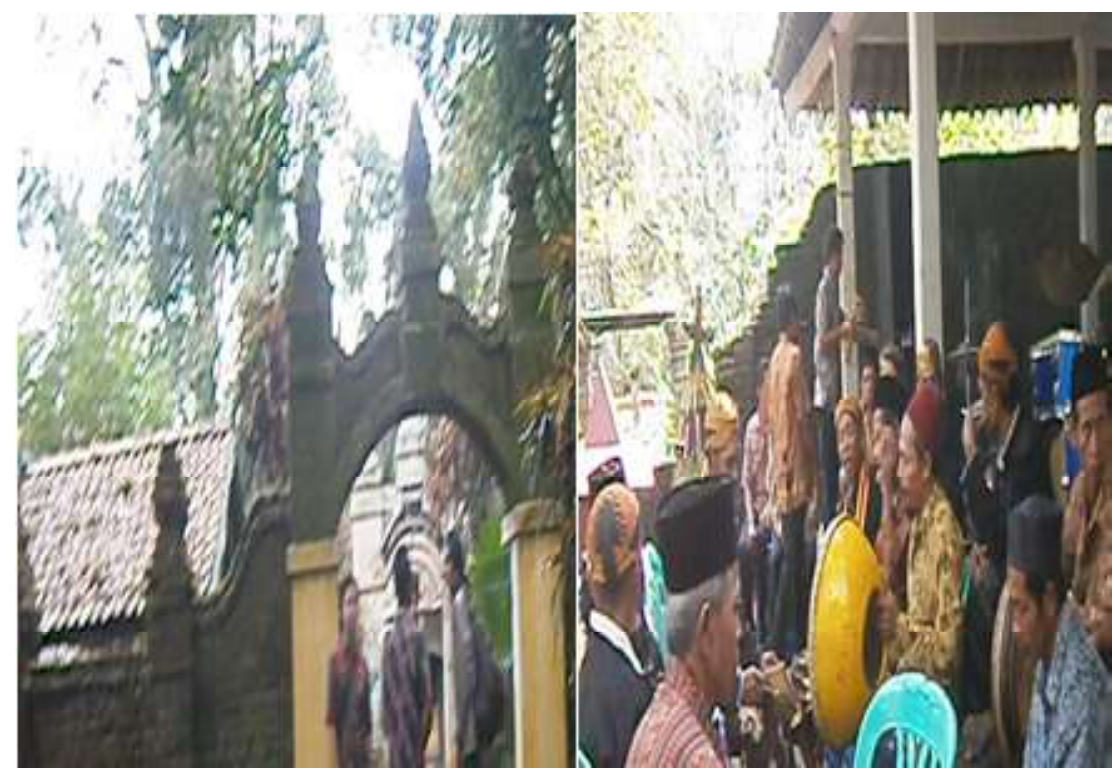

Gambar 2. Suasana Nyadran di Pemakaman Girilangan

Sepeninggal Ki Ageng Gumelem, wilayah kademangan ini dipimpin oleh seorang demang secara turun-temurun, hingga akhirnya wilayah ini terbagi menjadi dua: Desa Gumelem Wetan dan Gumelem Kulon sampai sekarang. Saat ini wilayah Kademangan Gumelem menjadi Desa Gumelem Wetan dan Gumelem Kulon Kecamatan Susukan Kabupaten Banjarnegara. Konon, asal mula terbaginya wilayah ini terjadi ketika seorang demang ingin mengalihkan kekuasaan kepada anaknya, namun si anak sedang berguru di luar wilayah Gumelem. Akhirnya demang tersebut menunjuk demang baru yang bukan keturunannya. Beberapa waktu kemudian, si anak pulang ke Gumelem. Menghindari terjadinya perebutan kekuasaan, Ki Demang membagi wilayah kademangan Gumelem menjadi dua: Kademangan Gumelem Wetan diberikan kepada putranya, dan Kademangan Gumelem Kulon diberikan kepada 
Sofa Marwah: Dinamika Kekuasaan, Islam dan Warisan Budaya di Banjarnegara

(hal. 153-172)

demang baru yang ditunjuk (Rachman, 2010).

Sejarah perkembangan Gumelem tentu tidak lepas dari statusnya yang pernah menjadi desa perdikan. Pada saat itu, penguasa perdikan diperkenankan memakai payung songsong atau payung kebesaran tanda kebesaran kerajaan. Perdikan berawal dari kata mardhika. Alasan pemberian stat us perdikan karena untuk memajukan agama, memelihara makam raja atau pusaka kerajaan, memelihara pertanahan, langgar, masjid dan sebagainya. Secara turun temurun, pengganti demang adalah keturunan laki-laki seperti yang terjadi di Kademangan Gumelem sejak era Ki Ageng Gumelem. Namun bila seorang demang tidak memiliki anak laki-laki, maka penggantinya dapat dari golongan alim ulama yang disegani dari daerah tersebut. Ketokohan Ki Ageng Gumelem diabadikan dengan pembangunan pendapa yang terletak di kompleks makam Ki Ageng Gumelem.

Stat us perdikan Gumelem bertahan sampai kekuasaan kolonial Belanda yang juga memberikan ketentuan bebas pajak. Seiring dengan ketetapan pemerintah Orde Lama melalui Undang-undang No. 13 Tahun 1946 mengenai penghapusan desa-desa perdikan, maka status Gumelem sebagai daerah perdikan juga dihapus. Dalam ketentuan tersebut yang disebutkan bahwa desa perdikan dalam ketatanegaraan kolonial Belanda dinamakan sebagai vrije desa. Adapun penghapusan status sebagai vrije desa mengingat keadaan dan kepentingan masing-masing daerah. Pada umumnya penetapan stat us sebuah daerah sebagai perdikan ditetapkan melalui prasasti oleh kerajaan. Seperti diketahui bahwa sejak masa Kerajaan Mataran kuno, tradisi membuat prasasti berkaitan dengan keberadaan wilayah sebagai kerajaan agraris, sehingga sebagian besar prasasti berkaitan dengan masalah perubahan status tanah. Pembuatan prasasti antara lain meliputi penetapan daerah menjadi sima atau swantatra, yang dalam perkembangannya disebut daerah perdikan unt uk menyebut daerah yang memiliki otonomi (Suhadi, 1981). Namun sayangnya dalam konteks penetapan Gumelem sebagai wilayah perdikan, studi ini belum menemukan prasasti yang menjelaskan ketetapan tersebut.

Saat ini jejak Kademangan Gumelem ini dapat dilihat dari pintu gerbang tua yang menjadi saksi kejayaan Kademangan Gumelem di masa lalu, serta beberapa bangunan rumah yang menyiratkan bentuk rumah-rumah keraton Jawa pada masa dulu. Selain itu, pemakaman Girilangan, untuk menyebut makam Ki Ageng Gumelem dan Ki Ageng Giring, telah menjelma sebagai kekayaan budaya masyarakat Gumelem. Selain menjadi wisata ziarah, 
pemakaman Girilangan juga menjadi menjadi pusat nyadran gede Kabupaten Banjarnegara pada setiap tahunnya. Selain itu, menurut keterangan juru kunci makam Girilangan, secara umum masyarakat Desa Gumelem juga meyakini kalau tradisi nyadran tidak dilaksanakan akan terjadi malapetakan atau gangguan yang tidak diinginkan (radarbanyumas.co.id diakses 18 Januari 2017). Nyadran gede tersebut diikuti oleh Bupati dan Wakil Bupati Banjarnegara beserta jajarannya di lingkungan Pemkab Banjarnegara. Nyadran gede merupakan ritual yang dilakukan tiap tahun unt uk menyambut datangnya Bulan Ramadan. Sesungguhnya, tradisi nyadran tersebut juga merupakan bent uk pelestarian tradisi zaman kademangan. Diiringi lant unan sholawat yang dipadukan dengan musik tradisional, masyarakat Gumelem berjalan beriringan dengan menggunakan pakaian adat Jawa membawa hasil-hasil bumi, menuju pemakaman Girilangan. Sebelum nyadran tiba, masyarakat sekitar juga melakukan bersih-bersih lokasi makam.

Namun demikan, kejayaan kademangan di masa lalu sesungguhnya juga masih diwariskan oleh tradisi membatik masyarakat Gumelem. Batik Gumelem merupakan batik tradisional yang diwariskan oleh keluarga Kademangan Gumelem pada masa kekuasaan Mataram. Pada awalnya, batik Gumelem dikerjakan oleh keluarga kedemangan sebagaimana asal mula kain batik di Pulau Jawa yang berawal dari tradisi di lingkungan keraton. Kata batik berasal dari bahasa Jawa, "amba" yang mempunyai arti "menulis" dan "titik". Kata batik merujuk pada kain dengan corak atau gambar yang dihasilkan oleh bahan yang disebut dengan "malam" yang diaplikasikan ke atas kain, sehingga menahan masuknya bahan pewarna.

Jika dikaitkan dengan ikatan genealogis dan kulturalnya, batik Gumelem merupakan salah satu industri kerajinan batik Jawa dalam lingkup batik Banyumasan, yang memiliki karakteristik yang khas pada corak dan warna. Konon, corak khas tersebut lahir dari filosofi dan akar budaya daerah. Adapun batik Banyumasan tersebar di wilayah Banyumas, Sokaraja, Banjarnegara, Tegal, Bentarsari (Brebes), Pejagoan dan Gemeksekti (Kebumen). Dalam hal ini Batik Gumelem memiliki motif batik seperti kopi pecah sodagaran, ukel, jahe serimpang, godhong lumbu, pring sedhapur, gajah uling, sungai serayu, udan liris, grinting, galaran, buntelan, ukir udar, sekar jagad, gabah wutah, blaburan, parang angkrik, rujak senthe, dan sebagainya. Batik Gumelem memiliki kekhasan tersendiri berbeda dengan motif batik daerah lain, antara lain warna yang terang, motifnya besar-besar. 


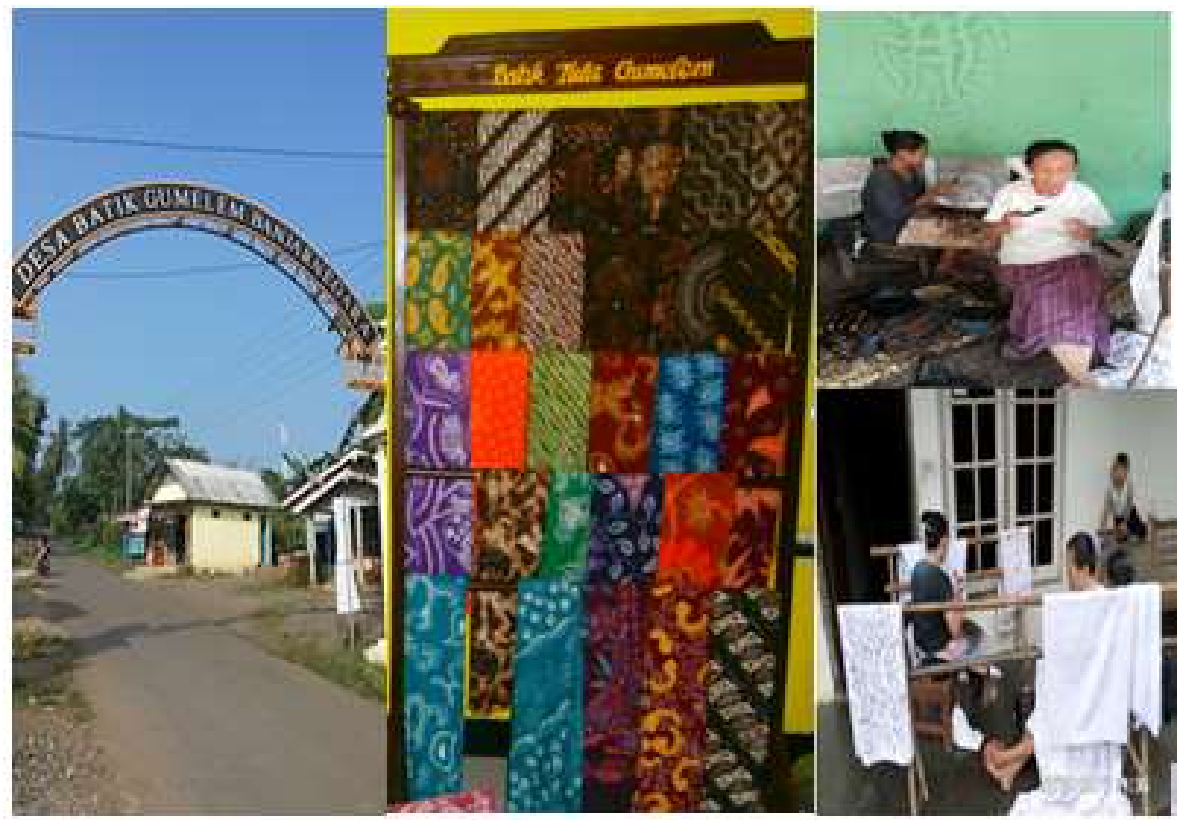

Gambar 3. Batik Gumelem

Seiring dengan penghapusan status Kademangan Gumelem, maka tradisi menghasilkan batik tradisional secara perlahan juga ikut menurun. Seperti diketahui bahwa batik merupakan warisan budaya immaterial yang berasal dari kerajinan keluarga keraton. Dalam hal ini keberadaan keluarga kademangan masih memiliki hubungan kekerabat an dengan keraton, sehingga tradisi batik yang dimiliki keluarga keraton juga ikut berkembang di wilayah kademangan tersebut. Batik klasik Gumelem dipengaruhi gaya keraton Mataraman Solo dan Yogyakarta, di mana corak dan motif batik hampir sama dengan corak yang dibawa oleh abdi dalem kerabat keraton. Ciri khas batik Gumelem terdapat pada warnanya yang tajam dan blok warna hitam. Adapun dasar warna tersebut konon merupakan kesepakatan masyarakat setempat (Rachman, $2010: 32$ ).

Setelah sekian waktu terjadi penurunan tradisi membatik di Desa Gumelem Wetan dan Gumelem Kulon dalam waktu yang cukup lama, tradisi batik Gumelem mulai dirintis kembali oleh salah satu keturunan demang yang juga pernah menjabat sebagai Kepala Desa Gumelem Wetan. Saat ini, industri batik Gumelem mulai juga berkembang di luar Desa Gumelem Wetan dan Gumelem Kulon, yaitu Desa Penarusan di Kecamatan Susukan. Dalam hal ini, 
studi Ardhanariswari (2014) memperlihatkan bahwa perempuan berperan penting dalam menjaga tradisi sebagai perajin batik maupun pelaku usaha batik lokal. Sayangnya perkembangan batik Gumelem yang cukup baik tersebut saat ini mendapatkan ancaman dari perkembangan batik printing yang lebih murah dan peningkatan industri batik dari daerah-daerah lain yang semakin kompetitif.

Seiring dengan era keterbukaan pada masa reformasi, perkembangan kebijakan budaya banyak dipengaruhi oleh munculnya politik identitas etnik serta desentralisasi yang memberi ruang bagi daerah untuk mengelola kebijakan daerah secara otonom. Berkaitan dengan desentralisasi pengelolaan budaya daerah pula, Pemkab Banjarnegara mulai tergerak untuk merawat tradisi batik tradisional sebagai warisan budaya yang sangat berharga. Dalam hal ini Pemkab Banjarnegara sudah berupaya untuk mendorong peningkatan industri batik Gumelem. Beberapa diantaranya, yaitu: 1) Pemkab Banjarnegara melalui Dekranasda memperkenalkan teknik pembuatan batik cap yang relatif lebih terjangkau harganya, segmen pasar lebih luas, dan prosesnya lebih cepat; 2) Dekranasda juga melakukan berbagai kegiatan seperti lomba rancang busana dan motif asli batik Gumelem, memberikan bantuan peralatan pembuatan batik tulis dan batik cap, pelatihan pewarnaan, lomba rancang motif dan busana batik Gumelem setiap dua tahun sekali, serta pemberian pinjaman modal dengan bunga rendah; 3) Dikeluarkannya Surat Edaran pertama dari Bupati Jasri mengenai keharusan menggunakan batik Gumelem sebagai seragam PNS Pemkab Banjarnegara pada setiap hari Sabtu, yang dilanjutkan dengan keluarnya SK Bupati Banjarnegara No.025/ 591 Tahun 2009 tentang Penggunaan Pakaian Dinas PNS di Lingkungan Pemkab Banjarnegara, yang memperpanjang penggunaan pakaian batik menjadi tiga hari, yaitu hari Kamis, Jumat, dan Sabtu. Selanjutnya pada tahun 2013 ditetapkan Perbup No. 47 Tahun 2013 tentang Pakaian Dinas di Lingkungan Pemerintah Kabupaten Banjarnegara, yang menyatakan bahwa pakaian dinas harian salah sat unya adalah batik yang merupakan produk daerah dan dipakai pada hari dan acara tertentu (Ardhanariswari, 2014).

Komitmen pemerintah daerah untuk mempertahankan tradisi dan budaya di Desa Gumelem Wetan dan Gumelem Kulon juga dikukuhkan dengan dikeluarkannya SK Bupati Banjarnegara No.556/1209 Tahun 2011 tentang Penetapan Desa-Desa di Kabupaten Banjarnegara sebagai Desa Wisata, yang antara lain mengat ur penetapan Desa Gumelem Wetan dan Gumelem Kulon 
sebagai desa wisata. Selanjutnya, sejak Tahun 2015 Pemkab Banjarnegara juga mengadakan Gumelem Ethnic Carnival sebagai rangkaian dari acara Festival Serayu Banjarnegara yang digelar setiap tahun untuk memperingati Hari Jadi Kabupaten Banjarnegara.

\section{Simpulan}

Kajian mengenai dinamika kekuasaan dan Islam dari berbagai pelosok Nusantara selalu menghadirkan pendeskripsian yang unik dan khas. Sisi dinamika kekuasaan Banjarnegara memperlihatkan bahwa suksesi kekuasaan masih dipegang oleh trahing kusuma, rembesing madu atau mengandalkan keturunan sebagai bangsawan, yang pada saatnya berhadapan dengan kepentingan politik dan ekonomi, sehingga harus tunduk pada kekuatan kolonial ataupun penguasa yang lebih tinggi. Seiring dengan pergantian zaman, maka suksesi kekuasaan mengikuti model pemilihan kepala daerah secara nasional. Namun demikian, sisi historisme Banjarnegara sesungguhnya tidak pernah lekang oleh waktu. Kenyataannya, ketika kepala daerah telah terpilih melalui sistem modern, namun persent uhan dengan nilai historis tidak pernah hilang. Setiap tahun, pemerintah daerah menyelenggarakan kirab gede yang menandai terbent uknya Banjarnegara dan nyadran gede untuk menghormati leluhur mereka, yang dipimpin langsung oleh jajaran pimpinan daerah.

Di samping itu, dinamika kekuasaan di bumi Banjarnegara juga tidak dapat dipisahkan dari perkembangan Islam. Mereka yang menyebarkan Islam di wilayah Banjarnegara masih terkait dengan keberadaan Walisanga, yang menurunkan tokoh-tokoh besar di Banjarnegara. Dalam hal ini, Islam telah menjadi agama mayoritas, namun penguasaan Islam tetap bersandingan dengan nilai-nilai lokal yang tidak pernah luntur. Dalam konteks demikian, perkembangan Islam di Banjarnegara telah mewariskan keberadaan Islam sebagai agama yang paling banyak dipeluk dengan segenap adat istiadat lokal yang turut menyertai. Nyadran gede, dapat menjadi contoh mengenai hal itu. Selain itu, tradisi nyadran gede juga meninggalkan pesan bahwa di wilayah itu, khususnya di Gumelem, pernah ada daerah bawahan Mataram yang memiliki kekuasaan otonom, tidak membayar pajak. Daerah yang demikian tent unya merupakan wilayah yang istimewa karena menyimpan benda-benda peninggalan kerajaan dan keberadaan makam tokoh Islam di Banjarnegara. Penguasaan kerajaan terhadap wilayah bawahan juga menyisakan keeksotisan 
yang lain, yait u batik tradisional. Keberadaan batik Gumelem di Banjarnegara melengkapi sisa kejayaan Gumelem yang pernah menjadi daerah perdikan atau dengan kata lain, daerah istimewa. Batik tradisional juga turut menjadi saksi sejarah berlangsungnya kekuasaan pada masa lalu dari satu generasi ke generasi berikutnya. Untuk itu keberadaannya pat ut dilestarikan oleh masyarakat dan pemerintah saat ini ataupun kelak. Terakhir, studi ini menekankan pentingnya studi lanjutan mengenai dinamika kekuasaan dalam masingmasing periode kekuasaan di Banjarnegara, sehingga mampu menghadirkan kajian yang lebih mendalam mengenai masing-masing periode kekuasaan tersebut. Studi demikian yang sangat penting untuk menghadirkan sisi historis, kekuasaan dan Islam di Banjarnegara secara lebih komprehensif.

\section{Daftar Pustaka}

Adisarwono. 1992. Sejarah Banyumas, Purwokerto: Penerbit Satria Utama. Adisarwono. tanpa tahun. Banjarnegara: Sejarah dan Babadnya, Objek Wisata dan Budayanya, tanpa penerbit.

Ardhanariswari, Riris dan Marwah, Sofa. 2014. Pengembangan Model Putting-Out System untuk Perlindungan Hukum dan Pemberdayaan Perempuan Perajin Batik Banjarnegara, Laporan Penelitian Hibah Bersaing, Unsoed Purwokerto.

Atmo, Tri. tanpa tahun. Kilas Sejarah Purbalingga, Pemerintahan Kabupaten Purbalingga.

Bakker, Anton dan Zubair, Ahmad Charis. 1990. Metodologi Penelitian Filsafat. Yogyakarta: Penerbit Kanisius.

Herusatoto, Budiono. 2008. Banyumas: Sejarah, Budaya, Bahasa dan Watak, Yogyakarta: LKiS.

http://WWW. radarbanyumas.co.id diakses 12 Maret 2017.

Jones, Tod. 2015. Kebudayaan dan Kekuasaan di Indonesia: Kebijakan Budaya selama Abad ke -20 hingga Era Reformasi, Jakarta: KITLV dan Pustaka Obor.

Muljana, Slamet. 2009. Runtuhnya Kerajaan Hindu Jawa dan Timbulnya Negara-Negara Islam di Nusantara, Yogyakarta: LKiS. 
Sofa Marwah: Dinamika Kekuasaan, Islam dan Warisan Budaya di Banjarnegara

(hal. 153-172)

Mulyasari, Prima Nurahmi. 2014. "Modernisasi dan Tata Ruang Kota Purwokerto 1900-1935”, dalam Jurnal Patrawidya, Vol. 5 No.04 Desember.

Pambudi, Reko dan Murdiyastomo, Agus. 2013. "Perkembangan Sosial, Politik, Ekonomi di Kabupaten Temanggung 1834-1890”, dalam Jurnal Ilmu Sejarah Vol. 1, jurnal-online.uny ac.id, diakses tanggal 12 Maret 2017.

Perda No. 3 Tahun 1994 tentang Hari Jadi Kabupaten Banjarnegara, Banjarnegara: Pemerintah Kabupaten.

Perda No 10 Tahun 2015 tentang Hari Jadi Kabupaten Banyumas, Banyumas: Pemerintah Kabupaten.

Perbup No. 47 Tahun 2013 tentang Pakaian Dinas di Lingkungan Pemerintah Kabupaten Banjarnegara, Banjarnegara: Pemerintah Kabupaten.

Priyadi, Sugeng. 2002. Banyumas: Antara Jawa dan Sunda, Semarang: IKAPI. Priyadi, Sugeng. 2005. Babad Pasir dan Babad Banyumas, Laporan Penelitian Hibah Bersaing Dikti, Jakarta.

Priyadi, Sugeng. 2011. Sejarah Tradisi Penjamasan Pusaka Kalisalak dan Kalibening Banyumas, Purwokerto: FKIP Universitas Muhammadiyah Purwokerto.

Rachman, Lina. 2010. Banjarnegara Punya Batik, Banjarnegara: Banjarnegara Corner.

SK Bupati Banjarnegara No.025/591 Tahun 2009 tentang Penggunaan Pakaian Dinas PNS di Lingkungan Pemkab Banjarnegara, Banjarnegara: Pemkab.

SK Bupati Banjarnegara No.556/1209 Tahun 2011 tentang Penetapan DesaDesa di Kabupaten Banjarnegara sebagai Desa Wisata, Banjarnegara: Pemkab.

Sudarmo, Warwin dan Purwoko, Bambang, Sejarah Banyumas dari Masa ke Masa, tanpa tahun dan penerbit.

Suhadi, Machi. 1981. "Status Tanah/Desa Perdikan di Jawa, Suatu Catatan dari Prasasti Kuna", dalam Analisis Kebudayaan, Th. 1, No. 1, Jakarta: FS UI, h. 137-143.

Sunardjo, Unang. 1983. Meninjau Panggung Sejarah Pemerintahan Kerajaan Cirebon 1479-1809, Bandung: Tarsito. 
|もむ曰' Jurnal Kajian Islam dan Budaya

Supriyono, Agustinus. 2013. "Tinjauan Historis Jepara Sebagai Kerajaan Maritim dan Kota Pelabuhan", dalam Jurnal Paramita Unnes Semarang Vo. 23 Januari, h. 27-39.

Undang-Undang No. 13 Tahun 1946 tentang Penghapusan Desa-Desa Perdikan

Undang-Undang No. 32 Tahun 2004 tentang Pemerintahan Daerah, Jakarta: Kemenkumham.

Yulianingsih, Wiwik dan Hariyono. 2012. "Sejarah Kota Mojokerto (19181942)", dalam jurnal-online.um.ac.id, h. 1-15, diakses 12 Maret 2017. 